Cera, G., Mlouk, A., Cera, E., \& Shumeli, A. (2020). The Impact of Entrepreneurship Education on Entrepreneurial Intention. A Quasi-Experimental Research Design. Journal of Competitiveness, 12(1), 3956. https://doi.org/10.7441/joc.2020.01.03

\title{
THE IMPACT OF ENTREPRENEURSHIP EDUCATION ON ENTREPRENEURIAL INTENTION. A QUASI-EXPERIMENTAL RESEARCH DESIGN
}

\section{- Gentjan Cera, Abmad Mlouk, Edmond Cera, Arjan Shumeli}

\begin{abstract}
There is a dearth of studies focusing on the relationship between entrepreneurship education (EE) and entrepreneurial intention (EI) in post-communist transition countries. The aim of this paper is to investigate the impact of EE on EI in the context of a Balkan country. An analysis of covariance (ANCOVA) was performed in a quasi-experimental research design with a pre- and post-program setting. To ensure the comparability between two groups of individuals (those with formal EE and those with no formal EE), a propensity score matching (PSM) along with coarsened exact matching (CEM) methods were applied in an original dataset of 528 adults. The use of this triangulation method was intended to attain more robust results. Our research establishes the impact of EE upon EI, a finding which is consistent with previous studies conducted in developed countries. Thus, individuals with formal EE reflected a higher intention to start a business. These findings offer insights for government officials and leaders of higher education institutions responsible for developing curricula and policies aimed at motivating university graduates toward entrepreneurship upon graduation and or completion of an EE course of study.
\end{abstract}

Keywords: entrepreneurship, entrepreneurship education, entrepreneurial intention, transition country, competitiveness

JEL Classification: I23, I25, L26

Received: November, 2019

1st Revision: January, 2020

Accepted: January, 2020

\section{INTRODUCTION}

The existing literature on entrepreneurship largely supports the idea that becoming an entrepreneur is attributable to the links established between EE, EI and business creation (Kuratko, 2005; Rodrigues et al., 2012). In this respect, universities are considered quite critical in triggering the learning process and in transmitting the required know-how to society with the goal of enhancing entrepreneurial activities (Audretsch, 2017), which has been closely associated with economic growth (Bosma et al., 2018). Furthermore, capacity building in entrepreneurship is a perpetual policy engagement within the European Union (EU) (Packham et al., 2010). In light of these policies, member states should attach importance to the enhancement of entrepreneurial 
competencies, as these policies lead to start-up activities and job creation among young individuals (European Commission, 2012). This stance is congruent with the conclusions of a global report on entrepreneurship which proclaims that economic advancement and reduction of unemployment can be attained through policies designed to spur on entrepreneurship (Herrington \& Penny, 2017), with this educational policy commitment and the resultant education programs having been shown to be instrumental in promoting entrepreneurship (Fayolle et al., 2006). According to Kok et al. (2012), university graduates from EE programs are inclined to exhibit more positive attitudes and intentions towards becoming an entrepreneur.

Albania has long aspired to join the European Union. However, the country is faced with a host of issues and challenges, with competitiveness long regarded as the most pressing issue. Albanian enterprises are ill-prepared to compete against goods and services flooding the domestic market from the EU member states. Based upon a report on Global Competitiveness from the World Economic Forum, Albania ranked the 36th in Europe, with a total of 58.1 points, with Germany in the lead at 82.8 points within the EU ranking (Schwab, 2018). These findings show that competitiveness among Albanian businesses is considerably low. Taking into account these factors, this paper centers on entrepreneurial intention as a starting point toward boosting entrepreneurial activity and, consequently, competitiveness. A pressing question in this regard is how individuals can be motivated to launch a business, with a number of studies highlighting the role that an education system plays in promoting entrepreneurship (Fereidouni \& Masron, 2012; Martin et al., 2013). Keeping this in mind, the government and its agencies responsible for developing policies which target business start-ups should carefully consider the types of instruments and tools necessary for creating a population of much better educated individuals.

Despite the large number of students graduating from Albanian universities, only a relatively small number have ever considered establishing and running their own business. Data released from the statistics office in Albania shows that the start-up rate for new firms has been declining over the last three years (INSTAT, 2018a). Presently, approximately $80 \%$ of students at public universities are not exposed to any type of program with a focus on entrepreneurship. A steep unemployment rate has been reported in Albania among young people as compared with the rate among older citizens. The data indicate that the joblessness rate among 15-29 year olds is at about 23\%, whilst among the 30-64 year olds, it was around 9\% in 2018. EE in university curricula creates a young population with improved opportunities to start and run a business, and it is instrumental in cutting the unemployment among graduates. Consequently, developing EE programs should be a central concern for both university leaders and government policymakers.

The bulk of research on EI has been rather limited to developing economies as compared with developed ones (Krueger et al., 2000). Albania, a post-communist transition country, has continuously made strides towards EU accession. Within the span of this research, we have not been able to locate any study that has investigated factors influencing EI in Albania. It should be noted, however, that a handful of studies (Çera \& Çera, 2019; Dabic et al., 2012; Kittova \& Steinhauser, 2018; Misoska et al., 2016) have in fact been undertaken on EI generally in the Balkan countries, yet they fall short of examining closely the EE-EI relationship. Hence, there is a clear need to fill in a research gap regarding the relationship between EI and EE in post-communist transition Albania. 
In studying the influence of EE on EI, a rigorous methodology should be put into practice, e.g. the model suggested by Fayolle and Liñán (2014). This methodology compares two populations: an exposed group of individuals introduced to formal EE, and a control group who have not been introduced to formal EE. Even though this design has been utilized in this field (Oosterbeek et al., 2010; Sánchez, 2011), along with the adoption of covariance analysis (Volery et al., 2013), we have not found any paper that has employed such a rigid approach to achieving a resemblance between these two populations.

The principal postulation of our quasi-experimental design is that these two groups should be as close to each other as possible in terms of similarity (Stuart \& Rubin, 2008). In other similar studies, this postulation has not been reported. As far as this issue is concerned, the current paper endeavours to contribute in this regard by applying PSM and CEM methods that make the comparison of two groups possible.

Regarding the organization of the present paper, the section which immediately follows contains the theoretical background and literature review, while the research design, method and data are described in the succeeding section. Results and discussions are then described, followed by the conclusions.

\section{LITERATURE REVIEW}

Individual intentions have been used to account for self-prediction in terms of engagement in a certain behaviour (Ajzen, 1991). EIs are all about one's own intentions to run a business or to engage in a start-up activity (Bae et al., 2014). A wide-ranging debate among scholars has taken place regarding whether an individual's economic behaviour is completely self-determined, i.e. intentional (Bogatyreva et al., 2019; Fayolle \& Liñán, 2014; Krueger et al., 2000). Nevertheless, there is a gap between intention and action as such, as EI is not always turned into a start-up activity (Van Gelderen et al., 2015). A meta-analysis done by Armitage and Conner (2001) reports that the explained variance of action toward a start-up activity by EI is less than $30 \%$. Nevertheless, a large number of studies still emphasize that EI is a key antecedent to actual entrepreneurial activity (i.e. Lee et al., 2011), which is even sometimes referred to as the most accurate predictor (Krueger \& Carsrud, 1993).

In order to investigate EI, scholars have used human capital theory, the entrepreneurial event model, the theory of planned behaviour, the entrepreneurial self-efficacy perspective or a combination of these models (Schlaegel \& Koenig, 2014). Introduced by Becker in 1975, Human capital theory claims that attitudes and intentions are influenced by the knowledge, abilities and skills acquired through education (Becker, 1994). Shapero and Sokol (1982) developed the entrepreneurial event model, which represents a combination of social and cultural factors (perceived desirability, perceived feasibility, and propensity to act) which affect EI. The theory of planned behaviour was formulated by Ajzen (1991) and states that action is predicted by intention, which in turn is driven by the attitude toward a behaviour, subjective norms and perceived behavioural control. Actual action or behaviour is expected when the formation of intentions occurs. Chen et al. (1998) proposed the entrepreneurial self-efficacy perspective, a model which refers to a belief in one's own ability and skills to succeed in performing the tasks and fulfilling the roles related to entrepreneurship. 
Universities can foster entrepreneurship by focusing on their students (Gavurova, Belas, Kotaskova, \& Cepel, 2018; Jansen, van de Zande, Brinkkemper, Stam, \& Varma, 2015). The EE program is not seen only as a way to attract students, but also as an instrument which fosters entrepreneurship, thereby enhancing one's capability, skills and motivation to become any entrepreneur (Belas et al., 2019; Shirokova et al., 2018; Walter et al., 2013). Applying policies that stimulate students toward start-up activity by universities leads to new venture creation (Jansen et al., 2015). Moreover, entrepreneurship components of the university positively influence students' climate perceptions regarding entrepreneurship (Belas et al., 2017; Bergmann et al., 2018; Bergmann et al., 2016).

Scholars have consistently paid close attention to the EE-EI relationship (Martin et al., 2013; Wilson et al., 2007). A meta-analysis comprising 73 studies reveals a positive association between EE and EI (Bae et al., 2014). Likewise et al. (2016) indicated that students' EI is positively impacted by EE. Additionally, students less exposed to entrepreneurship reflected higher EI after being introduced to EE (Fayolle \& Gailly, 2015). Nevertheless, Entrialgo and Iglesias (2016) found that the students' motivation to become entrepreneurs is not affected directly by EE. To encourage students to become entrepreneurs, universities should develop programs that cover emotional dimension and critical thinking by enhancing entrepreneurial psychological and social skills (Farhangmehr et al., 2016). Based on the above discussion, the following hypothesis can be proposed: EI is affected by EE, after holding constant prior individual differences in EI, which can be rephrased as a research question: is there a significant positive difference in the EI scores for the treated group and the control groups while controlling their pre-test scores on this intention?

A discussion on covariates which allows for the comparability of treated and control groups in a quasi-experimental setting is quite crucial (Stuart \& Rubin, 2008). These covariates should relate to EI and not be affected by treatment assignment. In this respect, the inclusion of four covariates is argued favourably including the following: gender, age, personal income and employment status.

Generally speaking, males tends to show higher intention to become entrepreneurs (Babikova \& Bucek, 2019; Çera et al., 2018; Dabic et al., 2012; Goktan \& Gupta, 2015; Marlow \& Martinez Dy, 2018; Perez-Quintana et al., 2017). Haus et al. (2013) conducted a meta-analysis and revealed that gender influences to attitude towards start-ups, subjective norms and perceived behavioural control. With regard to the age analysis, scholars treat it as a control variable of the EE-EI relationship. Higher attitudes toward EI are manifested by individuals at certain ages (Goktan \& Gupta, 2015; Kibler, 2013). Similar results are found in relation to the linkage between age and start-ups (Lafuente \& Vaillant, 2013; Shirokova et al., 2018; Urbano et al., 2017). Low-income individuals tend to display lower intentions to start up and run a business rather than those with higher incomes. Hence, the income level is positively related to entrepreneurial activities (Urbano et al., 2017). It should be noted that what an individual is presently doing results in EI being impacted (Bhandari, 2012; Haus et al., 2013). Seniority at work might affect the relationship between EI and motivation-driven determinants. University students tend to act at suggestions being provided from family members and acquaintances (Gohmann, 2012; van Gelderen et al., 2008), while non-students including managers behave independently irrespective of such 
opinions on account of the fact that they venture on the basis of their experience (Haus et al., 2013). Nevertheless, in contrast to Kibler's (2013) findings, according to Kassean et al. (2015), one's prior encounter with entrepreneurial activity does not impact EI. Besides the above points, in order to be able to assess the influence of EE on EI, family setting, be it individual's parents working as government employees, being self-employed or on the payroll of others, figured as a control variable in the previous studies (Gohmann, 2012; Sánchez, 2011, 2013; Walter \& Block, 2016; Wilson et al., 2007). Overall, EI might be affected by employment status, income level, gender, and age. Consequently, these factors might be regarded as suitable covariates ensuring the similarities between the treated and control groups.

\section{AIM, RESEARCH DESIGN AND DATA}

The aim of the current research is to investigate the impact of EE on the individuals' EI in the context of a Balkan country by applying rigor procedures. A quasi-experimental research design using propensity score matching (PSM) and coarsened exact matching (CEM) methods was used to create two similar groups from a randomly-selected sample: one comprises individuals who have attended a study program on entrepreneurship (treated group) and the other includes individuals who did not attend a similar program (control or comparison group). This type of setting requires a pre-program score and a post-program score for treated and control groups (Trochim et al., 2016). The term 'program' refers to a study program in entrepreneurship offered by universities. An EE is any study program of education which contributes to acquiring entrepreneurial attitudes and skills (Bae et al., 2014). The question centred upon EE was: Have you ever attended a subject in entrepreneurship? Respondents had to choose between two options: Yes or No. Individuals who picked No were considered as participants in the control group, while those who responded with a Yes were in the treated group.

The pre- and post-program scores were related to EI. Thus, the pre-program score represents one's score on EI before the program on entrepreneurship was introduced (Before_EI), while the post-program score is his/her score on EI after the program was finished (After_EI). EI was measured by a four-point scale item as recommended by several recent studies (SánchezEscobedo et al., 2011; Shinnar et al., 2012; Veciana et al., 2005). EI was addressed by a specific question: Have you ever thought of starting a business? Response options were: [1] No, never; [2] Yes, vaguely; [3] Yes, seriously; [4] Yes, I have a definite plan to start my own business.

To measure the effects of the EE on EI, a comparison of treated and control groups was carried out. This leads inevitably to the requirement of making two groups comparable. In order to do so, PSM and CEM methods were used. The principle of these methods is 'matching', which is linked to any method that aims to 'balance' the distribution of covariates in the control and treated groups. A covariate is a variable that might affect the dependent variable. To establish the possibilities of comparison between two methods, the same set of covariates was used in both methods, which consists of gender (female/male), age (scale variable), income (nominal variable) and employment status (nominal variable).

Both PSM and CEM are nonparametric matching applicable in a quasi-experimental design to balance the distribution of covariates in two groups. The purpose of applying them is to use a 
rigid and solid methodology and to ensure a triangulation of the results in terms of employing different matching methods. PSM, developed by Rosenbaum and Rubin (1983), is a method intended to adjust a treatment effect for measured covariates. PSM estimates the probability of being treated based on measured covariates, which is known as the propensity score (Stuart, 2010). In this paper, a logistic regression was performed to calculate it. One-to-one nearest neighbour matching was applied, which means that one participant from the treated group is matched to one participant from the control group which has the most similar propensity score. The maximum allowed difference between two participants equalled to 0.15 was used. This is known as the caliper, which is expressed as the number of standard deviations of the distance.

CEM, developed by Iacus et al. (2012), matches the treated participants with the control ones by categorizing each of the covariates. According to this method, continuous covariates should be grouped under broader categories for matching. This categorization process is coarsening. In our set of covariate variables, only age was a continuous covariate that needed to be coarsened.

Tab. 1 - Matching summary according to PSM and CEM methods. Source: own research

\begin{tabular}{|l|c|c|c|c|c|c|c|c|c|c|}
\hline & \multicolumn{5}{|c|}{ PSM } & \multicolumn{6}{c|}{ CEM } \\
\hline & $\begin{array}{c}\text { Con- } \\
\text { trol }\end{array}$ & $\begin{array}{c}\text { Treat- } \\
\text { ed }\end{array}$ & Total & avg.d & L1 & $\begin{array}{c}\text { Con- } \\
\text { trol }\end{array}$ & $\begin{array}{c}\text { Treat- } \\
\text { ed }\end{array}$ & Total & LCS & L1 \\
\hline All & 328 & 200 & 528 & .129 & & 328 & 200 & 528 & & \\
\hline Matched & 196 & 196 & 392 & .022 & .31 & 269 & 173 & 442 & 70.31 & .187 \\
\hline Unmatched & 132 & 4 & 136 & & & 59 & 27 & 86 & & \\
\hline
\end{tabular}

Note: avg.d is the average of absolute standardized difference in means for used covariates, L1 is the multivariate imbalance measure statistic, LCS is the percentage of local common support.

Matching summary of two methods is introduced in Table 1. Due to the selection of one-to-one nearest matching procedure, PSM method matched 196 participants from each group, meanwhile CEM method matched 173 from the treated group with 269 from the control group. So, when PSM method was used, only 392 out of 528 participants were matched, whereas in CEM method, the total matches were 442 participants. The 'good-fit' of PSM method can be judged by looking at absolute standardized difference in terms of used covariates. A considerable improvement was achieved referring to the issue of ensuring similar groups. The average of absolute standardized difference in means for used covariates was reduced almost six times $(=.129 / .022)$ from before to after applying PMS method. On the other hand, CEM method calculates the multivariate imbalance measure L1, which measures the 'good-fit' of matching. It ranges from 0 to 1 and in general, if it figures below .2, it means that the matching method did a good balancing of covariates distribution in two groups (Iacus et al., 2011). In our case, this statistics was .187. Consequently, $81.3 \%$ of the density of the histograms of treated and control groups overlapped. By way of argument, after applying PSM and CEM methods, control and treated groups were similar. Thus, a comparison of two groups can be done and its results are not misleading.

To examine the impact of EE on EI, data gathered by a face-to-face survey conducted in urban areas of eight main regions in Albania by a market research company in Tirana (IDRA Research $\&$ Consulting) are used. For the purposes of this study, all respondents who did not meet the 
criteria were filtered out and these cases do not count in our final sample. The time frame of the fieldwork survey was May 2018. Overall, 528 successful interviews are valid for the study. Table 2 shows the sample profile before and after matching representing the actual distribution of students in tertiary education in Albania (INSTAT, 2018b). In case of PSM method, 392 respondents were matched, while CEM method matched 442 respondents.

Tab. 2 - Sample profile. Source: own research

\begin{tabular}{|c|c|c|c|c|}
\hline \multirow{4}{*}{ Gender } & Sample before & \multicolumn{2}{|c|}{ Sample after matching } \\
\hline \multirow{3}{*}{ Region } & Female & $\begin{array}{c}\text { matching } \\
(\mathrm{n}=528)\end{array}$ & $\begin{array}{c}\text { PSM } \\
(\mathrm{n}=392)\end{array}$ & $\begin{array}{c}\text { CEM } \\
(\mathrm{n}=442)\end{array}$ \\
\cline { 2 - 5 } & Male & $60.4 \%$ & $59.9 \%$ & $60.2 \%$ \\
\cline { 2 - 5 } & Durrës & $39.6 \%$ & $40.1 \%$ & $39.8 \%$ \\
\cline { 2 - 5 } & Elbasan & $6.6 \%$ & $7.4 \%$ & $7.2 \%$ \\
\cline { 2 - 5 } & Fier & $7.0 \%$ & $8.2 \%$ & $7.0 \%$ \\
\cline { 2 - 5 } & Gjirokastër & $5.3 \%$ & $4.3 \%$ & $5.2 \%$ \\
\cline { 2 - 5 } & Korçë & $10.2 \%$ & $4.6 \%$ & $5.0 \%$ \\
\cline { 2 - 5 } & Shkodër & $10.0 \%$ & $13.0 \%$ & $10.0 \%$ \\
\cline { 2 - 5 } & Tiranë (capital city) & $45.1 \%$ & $42.6 \%$ & $43.5 \%$ \\
\cline { 2 - 5 } & Vlorë & $10.4 \%$ & $9.2 \%$ & $10.9 \%$ \\
\hline
\end{tabular}

\section{RESULTS AND DISCUSSION}

A one-way between subjects analysis of covariance (ANCOVA) is used to test whether EI is affected by attending a study program in entrepreneurship or not (EE or Program), after holding constant prior individual differences in EI. As suggested by several scholars (Tabachnick \& Fidell, 2013; Trochim et al., 2016; Volery et al., 2013), ANCOVA is the appropriate method to deal with the problems related to pre- and post-program settings. ANCOVA is an extension of analysis of variance (ANOVA) and is used by scholars to explore differences between groups while controlling for a covariate. In a pre- and post-program setting, ANCOVA increases the sensitivity of the test of main effects and interactions by reducing the error term (Tabachnick \& Fidell, 2013). This reduction in the error term is to be expected and attributed to the relationship between the dependent variable and the covariate. In our setting, Before_EI variable was used as covariate. EI was measured using a Likert-type scale. Before performing ANCOVA, its assumptions should be met. One of them is that the covariate (Before_EI) should not be statistically different across the levels of program (EE), which can be tested using a one-way ANOVA. This assumption was satisfied $(\mathrm{p}>.05)$ for both samples, for PSM, F(1, 390) $=2.473, \mathrm{p}=.117$, and for CEM samples, $\mathrm{F}(1,440)=3.299, \mathrm{p}=.07$. Both ANOVA's results fulfilled the assumption regarding the equality of error variances, since Levene's test was insignificant: $\operatorname{PSM}(\mathrm{F}(1,390)=$ $1.537, \mathrm{p}=.216)$, and CEM, $\mathrm{F}(1,440)=1.670, \mathrm{p}=.197$. 
The other assumption presented here is the homogeneity of regression slopes, which requires that the relationship between the covariate (Before_EI) and dependent variable (After_EI) for each of our groups be the same. It can be checked by running not a full factorial one-way ANCOVA with After_EI as the dependent variable and Program as the independent variable including Before_EI as the covariate and an interaction of Program with Before_EI. If the interaction is significant, then we have violated this assumption. In our case, in both PSM $(\mathrm{F}(1,390)=2.990$, $\mathrm{p}=.085)$ and $\operatorname{CEM}(\mathrm{F}(1,440)=2.342, \mathrm{p}=.127)$ samples, this interaction was not significant not risking the violation of the homogeneity of regression slopes. Satisfying these assumptions means that a one-way ANCOVA can be used and its results are not misleading.

Table 3 presents the number of participants, mean and standard deviation of Before_EI and After_EI for three samples: before applying matching, after applying PSM and CEM methods respectively. Performing the matching methods did not lead to significant differences in mean and standard deviation of EI. A difference in means of EI in both cases can be easily noticed: from the control group to the treated group, and from before and after introducing the program. If these differences result statistically significant, then there is enough evidence that supports the impact of EE on EI.

Tab. 3 - Mean and standard deviation of EI for control and treated groups Source: own research

\begin{tabular}{|c|c|c|c|c|c|c|c|c|c|c|}
\hline \multirow[t]{3}{*}{ EI } & \multirow[t]{3}{*}{ Group } & \multicolumn{3}{|c|}{ Before matching } & \multicolumn{6}{|c|}{ After matching } \\
\hline & & \multirow[t]{2}{*}{$\mathrm{n}$} & \multirow[t]{2}{*}{ Mean } & \multirow[b]{2}{*}{ SD } & \multicolumn{3}{|c|}{ PSM } & \multicolumn{3}{|c|}{ CEM } \\
\hline & & & & & $\mathrm{n}$ & Mean & SD & $\mathrm{n}$ & Mean & SD \\
\hline \multirow[t]{3}{*}{ Before } & Control & 328 & 1.555 & .830 & 196 & 1.582 & .828 & 269 & 1.565 & .829 \\
\hline & Treated & 200 & 1.725 & .913 & 196 & 1.719 & .905 & 173 & 1.717 & .899 \\
\hline & Total & 528 & 1.619 & .865 & 392 & 1.651 & .869 & 442 & 1.624 & .859 \\
\hline \multirow[t]{3}{*}{ After } & Control & 328 & 1.808 & .950 & 196 & 1.837 & .930 & 269 & 1.807 & .934 \\
\hline & Treated & 200 & 2.190 & 1.024 & 196 & 2.189 & 1.023 & 173 & 2.202 & 1.028 \\
\hline & Total & 528 & 1.953 & .995 & 392 & 2.013 & .992 & 442 & 1.962 & .990 \\
\hline
\end{tabular}

Note: SD is standard deviation.

A one-way between subjects ANCOVA was conducted to check whether EI is affected by EE or not, after holding constant prior individual differences in EI. The independent variable was the EE (Program) representing those who attended a study program in entrepreneurship (EE: Yes/ No), and the dependent variable After_EI. Participants' scores on EI before the program was introduced (Before_EI) were used as the covariate in this analysis. The results of the one-way ANCOVA for PSM and CEM samples are summarized in Table 4.

Preliminary checks were conducted to ensure that there was no violation of the ANCOVA's assumptions. After adjusting for the pre-program score on EI (Before_EI), there was a significant difference between the two groups (those attended a study program in entrepreneurship and those who did not) on After_EI. Judging by the values of the eta squares, the strength of this association was small. Quite similar results were found in both $\operatorname{PSM}(F(1,389)=11.773, \mathrm{p}=.001$, $\eta 2=.015)$ and CEM samples, $\mathrm{F}(1,439)=16.225, \mathrm{p}<.001, \eta 2=.018$. These findings support the effect of EE on EI. 
Tab. 4 - One-way ANCOVA results for PSM and CEM samples. Source: own research

\begin{tabular}{|l|l|l|l|l|l|l|l|l|l|l|}
\hline & \multicolumn{9}{|l|}{ PSM } & \multicolumn{9}{l|}{ CEM } \\
\hline Source & SS & df & F & p & $\eta^{2}$ & SS & df & F & p & $\eta^{2}$ \\
\hline $\begin{array}{l}\text { Corrected } \\
\text { model }\end{array}$ & 194.095 & 2 & 197.817 & .000 & .504 & 216.541 & 2 & 220.248 & .000 & .501 \\
\hline Intercept & 42.897 & 1 & 87.439 & .000 & .111 & 47.564 & 1 & 96.757 & .000 & .110 \\
\hline Before_EI & 181.95 & 1 & 370.877 & .000 & .473 & 200.062 & 1 & 406.974 & .000 & .463 \\
\hline Program & 5.776 & 1 & 11.773 & .001 & .015 & 7.976 & 1 & 16.225 & .000 & .018 \\
\hline
\end{tabular}

Note: Dependent variable: After_EI, SS is a sum of squares. The $\eta^{2}$ scores denote Cohen's (1988) effect sizes: $.01=$ small, $.06=$ medium, and $.14=$ large.

Furthermore, significant relationships were found between the scores in EI before the program was introduced and after finishing it. Furthermore, there were strong relationships between these scores as indicated by the eta squared greater than $.14\left(\eta^{2}=.473\right.$ and $\eta^{2}=.463$ for PSM and CEM samples respectively). This indicates that respectively $47 \%$ and $46 \%$ of the dependent variable (After_EI) was attributable to the Before_EI variable in PSM and CEM sample.

Figure 1 illustrates the values of estimated marginal means of After_EI for control (Program = No) and treated (Program $=$ Yes) groups representing EE in both PSM and CEM samples. These are the adjusted means for the dependent variable for each of our groups. The term 'adjusted' refers to the fact that the effect of the covariate (Before_EI) has been statistically removed (Tabachnick \& Fidell, 2013). As the graph shows, the PSM sample reflected an estimated marginal means which was a bit higher in both groups of Program (No/Yes) compared to the CEM sample. The reason for this may be linked to the fact that the CEM sample has a higher number of individuals in the control group and fewer individuals in the treated group than does the PSM sample (see Tab. 1). Moreover, in both samples, the estimated marginal means of After_EI of those who did not attend the program were a bit higher (1.891 and 1.853 for PSM and CEM respectively) compared to the sample means (1.837 and 1.807, refer to Table 3), while for those who attended the program, they were a bit lower (2.135 and 2.130) compared to the sample means (2.189 and 2.202, refer to Table 3). All things considered, the two matching methods reflect similar results.

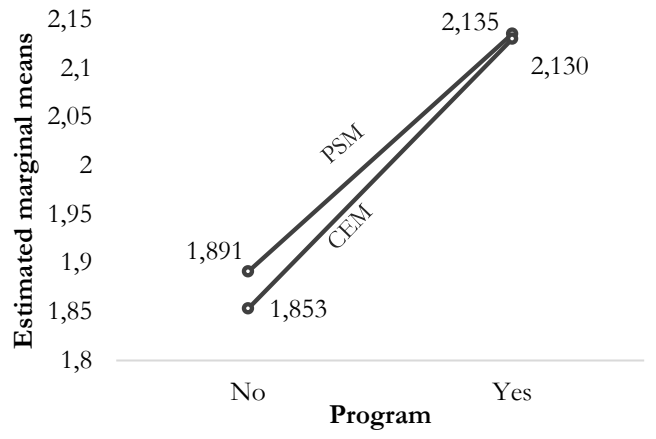

Fig. 1 - Estimated marginal means of After_EI for PSM and CEM samples (Source: own research) 
This research established that EI is positively influenced by EE courses provided by higher education institutions. Our findings are consistent with those arrived at in other studies undertaken in this field in advanced countries (Hahn et al., 2017; Iglesias-Sánchez et al., 2016; Sánchez, 2013). Even though the number of studies on EI is rather limited in the context of Balkan countries, our findings are consistent with one paper focusing on the case of Macedonia (Misoska et al., 2016). This adds value in terms of the studies since Albania and Macedonia share similar objectives when it comes to boosting and enhancing entrepreneurial activity.

These findings will most likely entail suggestions which will be useful for educational authorities and potential employers. Considering the scarcity in terms of entrepreneurial activity-based resources in Albania, higher education institutions programs should consider introducing entrepreneurship courses both to economic and non-economic study programs. Researchers have arrived at ample research-driven findings underscoring the significance of EE in promoting the student's intention to become an entrepreneur, be it in the field of engineering or science (Åstebro et al., 2012; Barba-Sánchez \& Atienza-Sahuquillo, 2018; Maresch et al., 2016; Westhead \& Solesvik, 2016). These results have been shown as far down as in the high school curriculum (Johansen et al., 2012; Rodrigues et al., 2012). In addition, efforts should be put into establishing focal-points with business organizations, continuous curriculum development, as well as fully integrated in-service training schemes (European Commission, 2016). As stated in the introductory section, EU member states are turning their attention to entrepreneurial skill development, as this leads to start-up activities and a reduction in the unemployment rate, especially among young individuals (European Commission, 2012). Albanian authorities have begun the adoption and implementation of an action plan on the basis of a model prescribed for establishing cooperation among universities, government, and business (European Commission, 2017).

Seen from a broader perspective, authorities should take care to establish a smooth-functioning educational system and a proactive business-focused policy (Brixiova \& Égert, 2017) which in turn, would contribute to an increasing number of resourceful individuals in entrepreneurship (La Porta \& Shleifer, 2014). Developing educational policies and curricula geared towards boosting students' capability and skills in entrepreneurial activities should be a priority for the Albanian government and higher education institutions in the country. Hence, as prescribed by Millán et al. (2014), policies aimed at higher education and entrepreneurship should be aligned. Enterprises, in collaboration with educational authorities, might well contemplate cultivating entrepreneurship by establishing a more amicable environment for graduate students to engage in internship programs (Filippetti \& Savona, 2017), as well as in government on the basis of the triple helix model (Feola et al., 2017; Kim et al., 2012). In addition to knowledge, education should be able to provide practical experience to students which will result in nurturing their abilities and competences toward the establishment of start-ups.

\section{CONCLUSION}

This paper further shows that education significantly impacts the intention of university students to engage in entrepreneurial activities by means of boosting capabilities and entrepreneurial drive. This is of the utmost significance since a course in EE leads to a higher EI in undertak- 
ing entrepreneurial activities. These findings are consistent with a research conducted in United Kingdom which has established that the majority of entrepreneur graduates are content with the results of their EE (Matlay, 2008).

The current research adds to the existing literature on entrepreneurship in at least two ways. It examines the benefits from developing the EE-EI relationship in post-communist transition Albania. Secondly, the combination of PSM and CEM methods is considered a sound methodological approach, and with both matching methods suggesting the same results, our findings are verified.

As discussed above, current research has been confined to just one post-communist transition country. Even though Albania might exhibit similar conditions regarding economic and political environment as is the case with other transition countries, the generalizability of findings may be limited, hence some precaution is advised in terms of transferring the results into another context. In addition, more covariates in PSM and CEM methods might be undertaken in future research. For example, family background and parents' occupation might be examined as factors which may influence an individual's entrepreneurial intention and behaviour (Gohmann, 2012), although some scholars claim that parents' education and employment status have a negligent effect on a person's behaviour (Kassean et al., 2015; Kibler, 2013).

Analysing the role played by both public and private universities in fostering EI remains an issue for future research. Although hardly any relevant impact was established in the case of Germany concerning the impact of privately-owned universities on budding entrepreneurs (Bergmann et al., 2016), a study on the controls for the type of higher education institutions on EI in postcommunist transition countries will prove to be of interest. With close reference to official data, approximately $7 \%$ of German students are enrolled in private higher educational institutions (Bergmann et al., 2018), while in the case of Albania the enrolment rate at private institutions hovers at around 20\% (INSTAT, 2018b). Public higher education institutions are assumed to be less market-oriented than private ones. Consequently, the EI among students enrolled in nonpublic universities is presumed to be much higher than that of those studying at a public university. This implication for future research is consistent with Kassean et al. (2015), who claim that the generalization of such findings might apply even beyond such circumstances.

\section{References}

1. Ajzen, I. (1991). The theory of planned behavior. Organizational Behavior and Human Decision Processes, 50 (2), 179-211. https://doi.org/10.1016/0749-5978(91)90020-T

2. Armitage, C. J., \& Conner, M. (2001). Efficacy of the Theory of Planned Behaviour: A meta-analytic review. British Journal of Social Psychology, 40 (4), 471-499. https://doi. org/10.1348/014466601164939

3. Åstebro, T., Bazzazian, N., \& Braguinsky, S. (2012). Startups by recent university graduates and their faculty: Implications for university entrepreneurship policy. Research Policy, 41 (4), 663-677. https://doi.org/10.1016/J.RESPOL.2012.01.004

4. Audretsch, D. B. (2017). Entrepreneurship and universities. International Journal of Entrepreneurship and Small Business, 31 (1), 4-11. https://doi.org/10.1504/IJESB.2017.083802 
5. Babikova, K., \& Bucek, J. (2019). A Model Replication with an Extension of Students' Perception of Prospective Employer Attractiveness. Journal of Competitiveness, 11 (2), 5-21. https://doi.org/10.7441/joc.2019.02.01

6. Bae, T. J., Qian, S., Miao, C., \& Fiet, J. O. (2014). The Relationship Between Entrepreneurship Education and Entrepreneurial Intentions: A Meta-Analytic Review. Entrepreneurship Theory and Practice, 38 (2), 217-254. https://doi.org/10.1111/etap.12095

7. Barba-Sánchez, V., \& Atienza-Sahuquillo, C. (2018). Entrepreneurial intention among engineering students: The role of entrepreneurship education. European Research on Management and Business Economics, 24 (1), 53-61. https://doi.org/10.1016/J. IEDEEN.2017.04.001

8. Becker, G. S. (1994). Human capital revisited. In Human Capital: A Theoretical and Empirical Analysis with Special Reference to Education. 15-28. Chicago: The university of Chicago press.

9. Belas, J., Gavurova, B., Korony, S., \& Cepel, M. (2019). Attitude of University Students toward entrepreneurship environment and toward entrepreneurship propensity in Czech Republic and Slovak Republic - International Comparison. Economic Research-Ekonomska Istrą̌ivanja, 32 (1), 2500-2514. https://doi.org/10.1080/1331677X.2019.1615972

10. Belas, J., Gavurova, B., Schonfeld, J., Zvarikova, K., \& Kacerauskas, T. (2017). Social and Economic Factors Affecting the Entrepreneurial Intention of University Students. Transformations in Business \& Economics, 16 (3), 220-239.

11. Bergmann, H., Geissler, M., Hundt, C., \& Grave, B. (2018). The climate for entrepreneurship at higher education institutions. Research Policy, 47 (4), 700-716. https:// doi.org/10.1016/J.RESPOL.2018.01.018

12. Bergmann, H., Hundt, C., \& Sternberg, R. (2016). What makes student entrepreneurs? On the relevance (and irrelevance) of the university and the regional context for student startups. Small Business Economics, 47 (1), 53-76. https://doi.org/10.1007/s11187-016-9700-6

13. Bhandari, N. C. (2012). Relationship between students' gender, their own employment, their parents' employment, and the students' intention for entrepreneurship. Journal of Entrepreneurship Education, 15 (1), 133-144. https://doi.org/10.1111/j.1559-1816.2002. tb00236.x

14. Bogatyreva, K., Edelman, L. F., Manolova, T. S., Osiyevskyy, O., \& Shirokova, G. (2019). When do entrepreneurial intentions lead to actions? The role of national culture. Journal of Business Research, 96, 309-321. https://doi.org/10.1016/J.JBUSRES.2018.11.034

15. Bosma, N., Content, J., Sanders, M., \& Stam, E. (2018). Institutions, entrepreneurship, and economic growth in Europe. Small Business Economics, 51 (2), 483-499. https://doi. $\operatorname{org} / 10.1007 / \mathrm{s} 11187-018-0012-\mathrm{x}$

16. Brixiova, Z., \& Égert, B. (2017). Entrepreneurship, institutions and skills in lowincome countries. Economic Modelling, 67, 381-391. https://doi.org/10.1016/J. ECONMOD.2017.02.020

17. Çera, E., \& Çera, G. (2019). Does entrepreneurship education impact individuals' entrepreneurial propensity? A pre- and post-program setting. In Proceedings of the European Conference on Innovation and Entrepreneurship, 229-237. Academic Conferences and Publishing International Limited. https://doi.org/10.34190/ECIE.19.160 
18. Çera, G., Cepel, M., Zakutna, S., \& Rozsa, Z. (2018). Gender differences in perception of the university education quality as applied to entrepreneurial intention. Journal of International Studies, 11 (3), 147-160. https://doi.org/10.14254/2071-8330.2018/11-3/13

19. Chen, C. C., Greene, P. G., \& Crick, A. (1998). Does entrepreneurial self-efficacy distinguish entrepreneurs from managers? Journal of Business Venturing, 13 (4), 295-316. https://doi.org/10.1016/S0883-9026(97)00029-3

20. Cohen, J. (1988). Statistical power analysis for the behavioral sciences. United States of America: L. Erlbaum Associates.

21. Dabic, M., Daim, T., Bayraktaroglu, E., Novak, I., \& Basic, M. (2012). Exploring gender differences in attitudes of university students towards entrepreneurship. International Journal of Gender and Entrepreneurship, 4 (3), 316-336. https://doi.org/10.1108/17566261211264172

22. Entrialgo, M., \& Iglesias, V. (2016). The moderating role of entrepreneurship education on the antecedents of entrepreneurial intention. International Entrepreneurship and Management Journal, 12 (4), 1209-1232. https://doi.org/10.1007/s11365-016-0389-4

23. European Commission. (2012). Rethinking Education: Investing in skills for better socio-economic outcomes. Strasbourg.

24. European Commission. (2016). Commission staff working document Albania 2016 Report. European Commission, Brussel.

25. European Commission. (2017). European Neighbourhood Policy and Enlargement Negotiations: 2017 SBA Fact Sheet Albania. Brussel.

26. Farhangmehr, M., Gonçalves, P., \& Sarmento, M. (2016). Predicting entrepreneurial motivation among university students: The role of entrepreneurship education. Education + Training, 58 (7/8), 861-881. https://doi.org/10.1108/ET-01-2016-0019

27. Fayolle, A., \& Gailly, B. (2015). The Impact of Entrepreneurship Education on Entrepreneurial Attitudes and Intention: Hysteresis and Persistence. Journal of Small Business Management, 53 (1), 75-93. https://doi.org/10.1111/jsbm.12065

28. Fayolle, A., Gailly, B., \& Lassas-Clerc, N. (2006). Assessing the impact of entrepreneurship education programmes: a new methodology. Journal of European Industrial Training, 30 (9), 701-720. https://doi.org/10.1108/03090590610715022

29. Fayolle, A., \& Liñán, F. (2014). The future of research on entrepreneurial intentions. Journal of Business Research, 67 (5), 663-666. https://doi.org/10.1016/j.jbusres.2013.11.024

30. Feola, R., Vesci, M., Botti, A., \& Parente, R. (2017). The Determinants of Entrepreneurial Intention of Young Researchers: Combining the Theory of Planned Behavior with the Triple Helix Model. Journal of Small Business Management. https://doi.org/10.1111/jsbm.12361

31. Fereidouni, H. G., \& Masron, T. A. (2012). Governance Matters and Entrepreneurial Activities. Thunderbird International Business Review, 54 (5), 701-712. https://doi.org/10.1002/ tie. 21494

32. Filippetti, A., \& Savona, M. (2017). University-industry linkages and academic engagements: individual behaviours and firms' barriers. Introduction to the special section. The Journal of Technology Transfer, 42 (4), 719-729. https://doi.org/10.1007/s10961-017-9576-x 
33. Gavurova, B., Belas, J., Kotaskova, A., \& Cepel, M. (2018). Management of education concepts in the field of entrepreneurship of university students in the Czech Republic. Polish Journal of Management Studies, 17 (2), 52-62. https://doi.org/10.17512/pjms.2018.17.2.05

34. Gohmann, S. F. (2012). Institutions, Latent Entrepreneurship, and Self-Employment: An International Comparison. Entrepreneurship Theory and Practice, 36 (2), 295-321. https://doi. $\operatorname{org} / 10.1111 / \mathrm{j} .1540-6520.2010 .00406 . x$

35. Goktan, A. B., \& Gupta, V. K. (2015). Sex, gender, and individual entrepreneurial orientation: evidence from four countries. International Entrepreneurship and Management Journal, 11 (1), 95-112. https://doi.org/10.1007/s11365-013-0278-z

36. Hahn, D., Minola, T., Van Gils, A., \& Huybrechts, J. (2017). Entrepreneurial education and learning at universities: exploring multilevel contingencies. Entrepreneurship \& Regional Development, 29 (9-10), 945-974. https://doi.org/10.1080/08985626.2017.1376542

37. Haus, I., Steinmetz, H., Isidor, R., \& Kabst, R. (2013). Gender effects on entrepreneurial intention: a meta-analytical structural equation model. International Journal of Gender and Entrepreneurship, 5 (2), 130-156. https://doi.org/10.1108/17566261311328828

38. Herrington, M., \& Penny, K. (2017). Global Entrepreneurship Monitor Global Report 2016/2017. Retrieved from http://www.gemconsortium.org/report/49812

39. Iacus, S. M., King, G., \& Porro, G. (2011). Multivariate Matching Methods That Are Monotonic Imbalance Bounding. Journal of the American Statistical Association, 106 (493), 345-361. https://doi.org/10.1198/jasa.2011.tm09599

40. Iacus, S. M., King, G., \& Porro, G. (2012). Causal Inference without Balance Checking: Coarsened Exact Matching. Political Analysis, 20 (1), 1-24. https://doi.org/10.1093/pan/ mpr013

41. Iglesias-Sánchez, P. P., Jambrino-Maldonado, C., Velasco, A. P., \& Kokash, H. (2016). Impact of entrepreneurship programmes on university students. Education + Training, 58 (2), 209-228. https://doi.org/10.1108/ET-01-2015-0004

42. INSTAT. (2018a). Active enterprises, New registration and Birth rate. Retrieved January 3, 2019, from http://databaza.instat.gov.al/

43. INSTAT. (2018b). Labour Market and Education, Education. Retrieved January 3, 2019, from http://www.instat.gov.al/en

44. Jansen, S., van de Zande, T., Brinkkemper, S., Stam, E., \& Varma, V. (2015). How education, stimulation, and incubation encourage student entrepreneurship: Observations from MIT, IIIT, and Utrecht University. The International Journal of Management Education, 13 (2), 170-181. https://doi.org/10.1016/J.IJME.2015.03.001

45. Johansen, V., Schanke, T., \& Hyvarde, T. (2012). Entrepreneurship Education and Pupils' Attitudes Towards Entrepreneurs. In T. Burger-Helmchen (Ed.), Entrepreneurship - Born, Made and Educated, 113-126. Rijeka, Croatia: InTech. https://doi.org/10.5772/35756

46. Kassean, H., Vanevenhoven, J., Liguori, E., \& Winkel, D. E. (2015). Entrepreneurship education: a need for reflection, real-world experience and action. International Journal of Entrepreneurial Behavior \& Research, 21 (5), 690-708. https://doi.org/10.1108/ IJEBR-07-2014-0123 
47. Kibler, E. (2013). Formation of entrepreneurial intentions in a regional context.

Entrepreneurship \& Regional Development, 25 (3-4), 293-323. https://doi.org/10.1080/08985626. 2012.721008

48. Kim, Y., Kim, W., \& Yang, T. (2012). The effect of the triple helix system and habitat on regional entrepreneurship: Empirical evidence from the U.S. Research Policy, 41 (1), 154-166. https://doi.org/10.1016/J.RESPOL.2011.08.003

49. Kittova, Z., \& Steinhauser, D. (2018). The International Economic Position of Western Balkan Countries in Light of their European Integration Ambitions. Journal of Competitiveness, 10 (3), 51-68. https://doi.org/10.7441/joc.2018.03.04

50. Kok, J. D., Snijders, J. A., Smit, L., Der, B. V., \& Linden. (2012). Effects and impact of entrepreneurship programmes in higher education. Brussels: European Commision.

51. Krueger, N. F., \& Carsrud, A. L. (1993). Entrepreneurial intentions: Applying the theory of planned behaviour. Entrepreneurship \& Regional Development, 5 (4), 315-330. https://doi. org/10.1080/08985629300000020

52. Krueger, N. F., Reilly, M. D., \& Carsrud, A. L. (2000). Competing models of entrepreneurial intentions. Journal of Business Venturing, 15 (5-6), 411-432. https://doi.org/10.1016/S08839026(98)00033-0

53. Kuratko, D. F. (2005). The Emergence of Entrepreneurship Education: Development, Trends, and Challenges. Entrepreneurship Theory and Practice, 29 (5), 577-598. https://doi. org/10.1111/j.1540-6520.2005.00099.x

54. La Porta, R., \& Shleifer, A. (2014). Informality and Development. Journal of Economic Perspectives, 28 (3), 109-126. https://doi.org/10.1257/jep.28.3.109

55. Lafuente, E. M., \& Vaillant, Y. (2013). Age driven influence of role-models on entrepreneurship in a transition economy. Journal of Small Business and Enterprise Development, 20 (1), 181-203. https://doi.org/10.1108/14626001311298475

56. Lee, L., Wong, P. K., Foo, M. Der, \& Leung, A. (2011). Entrepreneurial intentions: The influence of organizational and individual factors. Journal of Business Venturing, 26 (1), 124-136. https://doi.org/10.1016/J.JBUSVENT.2009.04.003

57. Maresch, D., Harms, R., Kailer, N., \& Wimmer-Wurm, B. (2016). The impact of entrepreneurship education on the entrepreneurial intention of students in science and engineering versus business studies university programs. Technological Forecasting and Social Change, 104, 172-179. https://doi.org/10.1016/J.TECHFORE.2015.11.006

58. Marlow, S., \& Martinez Dy, A. (2018). Annual review article: Is it time to rethink the gender agenda in entrepreneurship research? International Small Business Journal: Researching Entrepreneurship, 36 (1), 3-22. https://doi.org/10.1177/0266242617738321

59. Martin, B. C., McNally, J. J., \& Kay, M. J. (2013). Examining the formation of human capital in entrepreneurship: A meta-analysis of entrepreneurship education outcomes. Journal of Business Venturing, 28 (2), 211-224. https://doi.org/10.1016/J.JBUSVENT.2012.03.002

60. Matlay, H. (2008). The impact of entrepreneurship education on entrepreneurial outcomes. Journal of Small Business and Enterprise Development, 15 (2), 382-396. https://doi. org/10.1108/14626000810871745 
61. Millán, J. M., Congregado, E., Román, C., van Praag, M., \& van Stel, A. (2014). The value of an educated population for an individual's entrepreneurship success. Journal of Business Venturing, 29 (5), 612-632. https://doi.org/10.1016/J.JBUSVENT.2013.09.003

62. Misoska, A. T., Dimitrova, M., \& Mrsik, J. (2016). Drivers of entrepreneurial intentions among business students in Macedonia. Economic Research-Ekonomska Istraživanja, 29 (1), 1062-1074. https://doi.org/10.1080/1331677X.2016.1211956

63. Oosterbeek, H., van Praag, M., \& Ijsselstein, A. (2010). The impact of entrepreneurship education on entrepreneurship skills and motivation. European Economic Review, 54 (3), 442-454. https://doi.org/10.1016/J.EUROECOREV.2009.08.002

64. Packham, G., Jones, P., Miller, C., Pickernell, D., \& Thomas, B. (2010). Attitudes towards entrepreneurship education: a comparative analysis. Education + Training, 52 (8/9), 568-586. https://doi.org/10.1108/00400911011088926

65. Perez-Quintana, A., Hormiga, E., Martori, J. C., \& Madariaga, R. (2017). The influence of sex and gender-role orientation in the decision to become an entrepreneur. International Journal of Gender and Entrepreneurship, 9 (1), 8-30. https://doi.org/10.1108/IJGE-12-20150047

66. Rodrigues, G. R., Dinis, A., Do, A., Ferreira, J., \& Raposo, M. (2012). The Effect of an Entrepreneurial Training Programme on Entrepreneurial Traits and Intention of Secondary Students. In T. Burger-Helmchen (Ed.), Entrepreneurship - Born, Made and Educated, 77-92. Rijeka, Croatia: InTech. https://doi.org/10.5772/35302

67. Rosenbaum, P. R., \& Rubin, D. B. (1983). The central role of the propensity score in observational studies for causal effects. Biometrika, 70 (1), 41-55. https://doi.org/10.1093/ biomet/70.1.41

68. Sánchez-Escobedo, M. de la C., Díaz-Casero, J. C., Hernández-Mogollón, R., \& PostigoJiménez, M. V. (2011). Perceptions and attitudes towards entrepreneurship. An analysis of gender among university students. International Entrepreneurship and Management Journal, 7 (4), 443-463. https://doi.org/10.1007/s11365-011-0200-5

69. Sánchez, J. C. (2011). University training for entrepreneurial competencies: Its impact on intention of venture creation. International Entrepreneurship and Management Journal, 7 (2), 239-254. https://doi.org/10.1007/s11365-010-0156-x

70. Sánchez, J. C. (2013). The Impact of an Entrepreneurship Education Program on Entrepreneurial Competencies and Intention. Journal of Small Business Management, 51 (3), 447-465. https://doi.org/10.1111/jsbm.12025

71. Schlaegel, C., \& Koenig, M. (2014). Determinants of Entrepreneurial Intent: A MetaAnalytic Test and Integration of Competing Models. Entrepreneurship Theory and Practice, 38 (2), 291-332. https://doi.org/10.1111/etap.12087

72. Schwab, K. (2018). The Global Competitiveness Report 2018. Geneva, Switzerland.

73. Shapero, A., \& Sokol, L. (1982). The Social Dimensions of Entrepreneurship. In C. A. Kent, D. L. Sexton, \& K. H. Vesper (Eds.), Encyclopaedia of entrepreneurship. New York, NY: Prentice Hall. 
74. Shinnar, R. S., Giacomin, O., \& Janssen, F. (2012). Entrepreneurial Perceptions and Intentions: The Role of Gender and Culture. Entrepreneurship Theory and Practice, 36 (3), 465-493. https://doi.org/10.1111/j.1540-6520.2012.00509.x

75. Shirokova, G., Tsukanova, T., \& Morris, M. H. (2018). The Moderating Role of National Culture in the Relationship Between University Entrepreneurship Offerings and Student Start-Up Activity: An Embeddedness Perspective. Journal of Small Business Management, 56 (1), 103-130. https://doi.org/10.1111/jsbm.12363

76. Stuart, E. A. (2010). Matching methods for causal inference: A review and a look forward. Statistical Science: A Review Journal of the Institute of Mathematical Statistics, 25 (1), 1-21. https:// doi.org/10.1214/09-STS313

77. Stuart, E. A., \& Rubin, D. B. (2008). Best Practices in Quasi-Experimental Designs: Matching Methods for Causal Inference. In J. Osborne (Ed.), Best Practices in Quantitative Methods. California: SAGE Publications, Inc. https://doi.org/10.4135/9781412995627.d14

78. Tabachnick, B. G., \& Fidell, L. S. (2013). Using multivariate statistics (6th ed.). Boston: Pearson Education.

79. Trochim, W. M. K., Donnelly, J. P., \& Arora, K. (2016). Research methods: the essential knowledge base (2nd ed.). Cengage Learning. Retrieved from https://www.cengage.co.uk/ books/9781133954774/

80. Urbano, D., Aparicio, S., Guerrero, M., Noguera, M., \& Torrent-Sellens, J. (2017). Institutional determinants of student employer entrepreneurs at Catalan universities. Technological Forecasting and Social Change, 123, 271-282. https://doi.org/10.1016/J. TECHFORE.2016.06.021

81. van Gelderen, M., Brand, M., van Praag, M., Bodewes, W., Poutsma, E., \& van Gils, A. (2008). Explaining entrepreneurial intentions by means of the theory of planned behaviour. Career Development International, 13 (6), 538-559. https://doi.org/10.1108/13620430810901688

82. Van Gelderen, M., Kautonen, T., \& Fink, M. (2015). From entrepreneurial intentions to actions: Self-control and action-related doubt, fear, and aversion. Journal of Business Venturing, 30 (5), 655-673. https://doi.org/10.1016/J.JBUSVENT.2015.01.003

83. Veciana, J. M., Aponte, M., \& Urbano, D. (2005). University Students' Attitudes Towards Entrepreneurship: A Two Countries Comparison. The International Entrepreneurship and Management Journal, 1 (2), 165-182. https://doi.org/10.1007/s11365-005-1127-5

84. Volery, T., Müller, S., Oser, F., Naepflin, C., \& del Rey, N. (2013). The Impact of Entrepreneurship Education on Human Capital at Upper-Secondary Level. Journal of Small Business Management, 51 (3), 429-446. https://doi.org/10.1111/jsbm.12020

85. Walter, S. G., \& Block, J. H. (2016). Outcomes of entrepreneurship education: An institutional perspective. Journal of Business Venturing, 31 (2), 216-233. https://doi. org/10.1016/J.JBUSVENT.2015.10.003

86. Walter, S. G., Parboteeah, K. P., \& Walter, A. (2013). University Departments and SelfEmployment Intentions of Business Students: A Cross-Level Analysis. Entrepreneurship Theory and Practice, 37 (2), 175-200. https://doi.org/10.1111/j.1540-6520.2011.00460.x 
87. Westhead, P., \& Solesvik, M. Z. (2016). Entrepreneurship education and entrepreneurial intention: Do female students benefit? International Small Business Journal, 34 (8), 979-1003. https://doi.org/10.1177/0266242615612534

88. Wilson, F., Kickul, J., \& Marlino, D. (2007). Gender, Entrepreneurial Self-Efficacy, and Entrepreneurial Career Intentions: Implications for Entrepreneurship Education. Entrepreneurship Theory and Practice, 31 (3), 387-406. https://doi.org/10.1111/j.15406520.2007.00179.x

\section{Contact information}

\section{Gentjan Cera}

Tomas Bata University in Zlin, Faculty of Management and Economics,

Czech Republic

E-mail:cera@utb.cr.

ORCID: 0000-0002-9324-181X

Prof. Ahmad Mlouk, PhD

Staffordshire University, Staffordshire Business School

United Kingdom

E-mail:A.Mlouk@staffs.ac.uk.

\section{Edmond Cera}

Tomas Bata University in Zlin, Faculty of Management and Economics

Crech Republic

E-mail:ecera@utb.cz.

ORCID:0000-0003-3546-2101

Assoc. Prof. Arjan Shumeli, PhD

Agricultural University of Tirana, Faculty of Economics and Agribusiness

Albania

E-mail:ashumeli@ubt.edu.al

ORCID: 0000-0002-3737-8176 